\title{
ANALIZA CIĘŻARU TORNISTRÓW WŚRÓD UCZNIÓW NAUCZANIA POCZĄTKOWEGO
}

\author{
ANALYSIS OF THE WEIGHT OF SCHOOLBAGS AMONG STUDENTS OF PRIMARY EDUCATION \\ Karina Słonka', Małgorzata Gryc², Martyna Chodakowska², Anna Klus² \\ ${ }^{1}$ Wydział Wychowania Fizycznego i Fizjoterapii, Politechnika Opolska, Polska \\ ${ }_{2}^{2}$ Studenckie Koło Naukowe Akton, Instytut Fizjoterapii, Wydział Wychowania Fizycznego i Fizjoterapii, Politechnika Opolska, Polska \\ DOI: https://doi.org/10.20883/ppnoz.2019.59
}

\begin{abstract}
STRESZCZENIE
Wstęp. Obecnie często kręgosłupy dzieci i młodzieży obciążane są zbyt ciężkimi tornistrami. Badania wykazują, że obciążenia plecakiem ważącym ponad 15\% masy ciała wpływają niekorzystnie na postawę ciała, chód i układ oddechowy. Ponadto stanowić mogą jedną z głównych przyczyn występowania dolegliwości bólowych kręgosłupa oraz wad postawy ciała i stóp.

Cel pracy. Celem pracy jest ocena ciężaru tornistrów wśród uczniów nauczania początkowego.

Materiał i metody. Badania przeprowadzono w maju 2017 r. w Publicznej Szkole Podstawowe nr 2 w Opolu. Przebadano 195 uczniów (106 chłopców i 89 dziewczynek) w wieku 7-9 lat uczęszczających do pierwszych trzech klas. Do oceny ciężaru tornistra z zawartością i pomiaru masy ciała badanych wykorzystano wagę elektroniczną TANITA, dodatkowo oceniono wysokość ciała uczniów. Badania przeprowadzono na zajęciach lekcyjnych w godzinach rannych. Wyniki. Przeprowadzone badania wykazały, że większość dzieci nosi zbyt ciężie tornistry. Zalecany w tym wieku, bezpieczny dla zdrowia dzieci trzykilogramowy ciężar plecaków występował w pojedynczych przypadkach. Natomiast tornistry przekraczające 15\% masy ciała dzieci stwierdzono u ponad 1/3 uczniów nauczania początkowego. Niepokojące jest to, że najciężzze plecaki w porównaniu do masy ciała nosiła ponad połowa badanych uczniów klas pierwszych.

Wnioski. Podjęcie zintegrowanych kroków mających za zadanie wyrobienie umiejętności prawidłowego pakowania tornistra oraz nawyku systematycznego kontrolowania jego zawartości i ciężaru może w przyszłości uchronić młode pokolenie przed przeciążeniami stawów i rozwojem wad postawy.
\end{abstract}

Słowa kluczowe: ciężar tornistrów, dzieci, nauczanie początkowe.

ABSTRACT

Introduction. Currently, often the backbones of children and adolescents are loaded with too heavy schoolbags. Studies show that backpack loads weighing more than $15 \%$ of body weight adversely affect body posture, gait and respiratory system. In addition, they can be one of the main causes of back pain, defects in body and feet posture.

Aim of the study. The aim of the study is to assess the weight of schoolbags among students of primary education.

Material and methods. The research was conducted in May 2017 at Public Primary School No. 2 in Opole. 195 students (106 boys and 89 girls) aged 7-9 attending the first three classes were examined. The TANITA electronic scale was used to assess the weight of the school bag with content and to measure the weight of the subjects, in addition, the students' height was assessed. Research was carried out in the classroom in the morning.

Results. Studies have shown that most children wear too heavy school satchels. The three-kilogram weight of backpacks recommended at this age, safe for children's health, occurred in individual cases. On the other hand, satchels exceeding $15 \%$ of the body weight of children were found in over $1 / 3$ of primary education students. It is distressing that the heaviest backpacks compared to body weight were worn by more than half of the first grade students surveyed.

Conclusions. Taking integrated steps to develop the ability to properly pack a school bag and the habit of systematical controlling its content and weight can in the future protect the young generation from overloading the joints and the development of posture defects.

Keywords: weight of schoolbags, children, initial education.

\section{Wstęp}

Problem ciężaru tornistrów noszonych przez dzieci jest często dyskutowany wśród specjalistów z różnych dziedzin. Ocena ciężaru tornistrów w wielu krajach, i w Polsce, wykazuje, że większość dzieci nosi zbyt ciężkie plecaki [1-4].

Badania prowadzone w różnych krajach pokazują, że zbyt ciężkie tornistry przekraczające 10\%-15\% masy ciała wpływają niekorzystnie na kształtującą się postawę ciała, układ oddechowy i chód oraz są przyczyną występowania dolegliwości bólowych u dzieci [5-10]. Mimo wielu badań wykazujących, że zbyt ciężki plecak niekorzystnie wpływa na postawę ciała i stanowi przyczynę dolegliwości bólowych kręgosłupa, w Polsce nadal nie określono limitu ciężaru tornistra, jaki mogą nosić dzieci. Centralny Instytut Pracy uważa, że dzieci nie powinny być obciążane cięża- 
rem tornistra większym niż 10-15\% masy ciała [2]. Normy te oczywiście są umowne. Często w gronie specjalistów dyskutuje się, czy normy te dostatecznie chronią dzieci przed przeciążeniami i czy procentowy limit noszonego na plecach balastu jest dobrym rozwiązaniem, szczególnie w sytuacji narastającego wśród u dzieci problemu nadwagi i otyłości. Badania wykazują, że obciążanie dodatkowym ciężarem dzieci z nadwagą i otyłością wpływa niekorzystnie na stopy, powodując zwiększenie obszaru kontaktu stopy z podłożem oraz przeciążenie przodostopia w porównaniu do rówieśników z prawidłową masą ciała [11].

Norma wagowa wydaje się szczególnie ważna dla prawidłowego rozwoju dzieci w wieku wczesnoszkolnym, gdyż narażone są one na częstsze występowanie wad postawy. Badania oceniające stan zdrowia dzieci wykazują, że nieprawidłowości w postawie ciała pojawiają się już u dzieci w wieku przedszkolnym. Częstość występowania zaburzeń posturalnych waha się od 30\% do 60\% [12, $13,14]$. Zaobserwowano, że występujące u dzieci przedszkolnych nieprawidłowości w postawie ciała w okresie szkolnym skutkują progresją [15, 16]. Przeprowadzone w 2005 r. analizy na podstawie dokumentacji pielęgniarek medycyny szkolnej ze szkół Opola wykazują, że problem występowania wad postawy u dzieci i młodzieży dotyczy 24\% populacji. Szczegółowa analiza w poszczególnych szkołach wskazuje, że w niektórych placówkach problem ten dotyka prawie $50 \%$ dzieci [17].

Dlatego $w$ trosce o zdrowie i bezpieczeństwo dzieci rozsądną propozycją byłoby wprowadzenie zaproponowanej przez pracowników Państwowej Inspekcji Sanitarnej normy obciążenia tornistrów dzieci w wieku wczesnoszkolnym do $3 \mathrm{~kg}$ [2].

\section{Cel pracy}

Celem pracy jest ocena ciężaru tornistrów wśród uczniów nauczania początkowego.

\section{Materiał i metoda}

Badania przeprowadzono w kwietniu 2017 r. w Publicznej Szkole Podstawowe nr 2 w Opolu wśród uczniów pierwszych trzech klas. Ogółem badaniami objęto grupę 195 uczniów w tym 106 chłopców i 89 dziewczynek w wieku 7-9 lat. W tabeli 1. zamieszczono podstawowe dane antropometryczne badanych z podziałem na płeć i wiek.

Do oceny ciężaru tornistra z zawartością oraz pomiaru masy ciała wykorzystano wagę elektroniczną TANITA, dodatkowo oceniono wysokość ciała uczniów. Badania przeprowadzono $w$ godzinach rannych na zajęciach lekcyjnych.
Tabela 1. Charakterystyka badanej grupy z uwzględnieniem płci i klasy

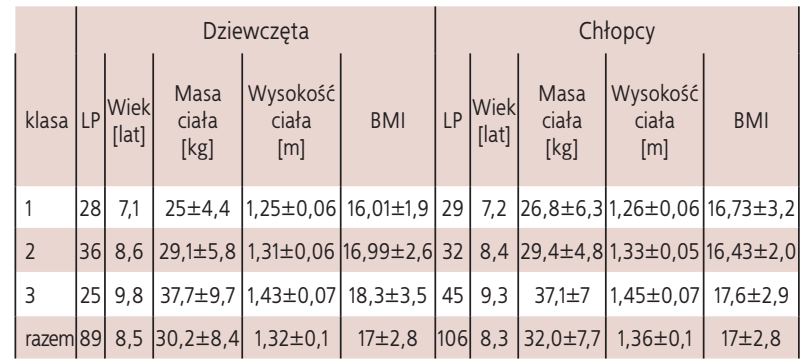

\section{Wyniki}

Przeprowadzone badania wykazały, że średni ciężar tornistra w badanej grupie wynosiła 4,1 kg. W porównaniu do średniej masy ciała badanych ciężar ten wynosił $14 \%$ ich masy ciała. Najcięższy plecak ważył $5,8 \mathrm{~kg}$, a naj|żejszy $2,5 \mathrm{~kg}$.

Szczegółowa analiza wyników wykazała, że tylko 13 uczniów $(6,7 \%)$ miało tornister, którego ciężar nie przekraczał 3 kilogramów.

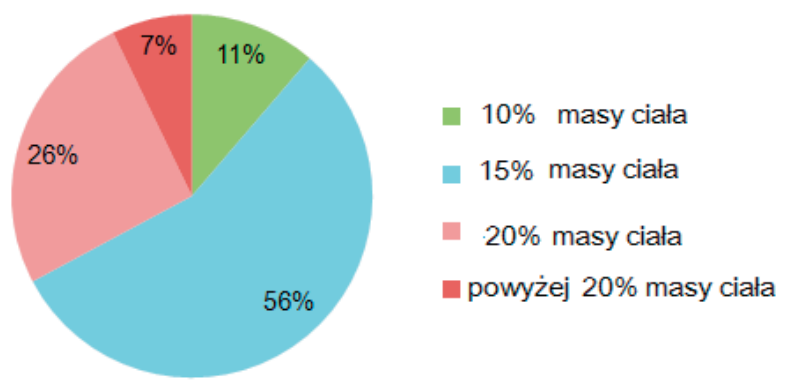

Rycina 1. Analiza procentowa ciężaru tornistrów w stosunku do masy ciała $w$ badanej grupie

Ocena procentowa ciężaru tornistra w stosunku do masy ciała wykazała, że jedynie $11 \%$ uczniów nosiło tornistry nie przekraczające $10 \%$ masy ciała. Niepokojące jest to, że 1/3 badanych dźwigała plecaki, których ciężar przekraczał $15 \%$ masy ciała.

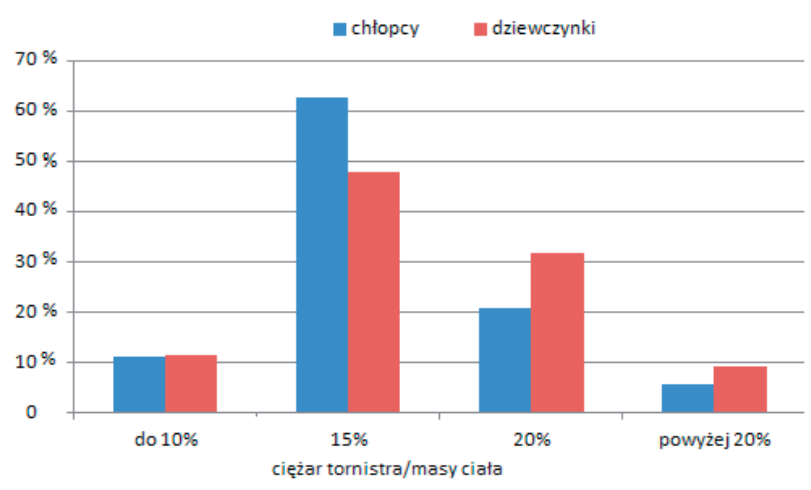

Rycina 2. Rozkład procentowy ciężaru tornistrów z uwzględnieniem płci 
Analizując rozkład procentowy ciężaru tornistrów w badanej grupie z uwzględnieniem płci zaobserwowano, że dziewczęta częściej (41\%) w porównaniu do chłopców (26\%) nosiły tornistry, których ciężar przekraczał 15\% masy ciała.

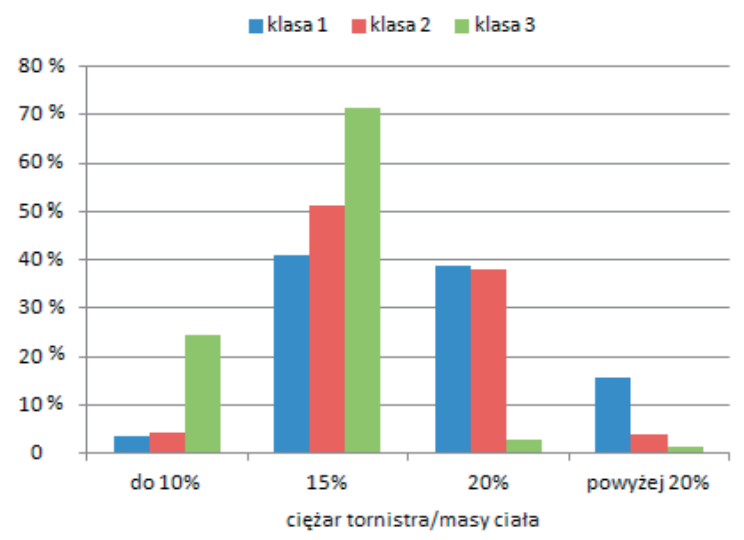

Rycina 3. Rozkład procentowy ciężaru tornistra w badanych klasach

Z obserwacji rozkładu ciężaru tornistra w badanych klasach wynika, że plecaki o ciężarze nie przekraczającym 10\% masy najczęściej występowały u trzecioklasistów. Ciężar plecaków uczniów z tych klas, w większości przypadków, mieścił się $w$ górnej granicy normy, czyli nie przekraczały $15 \%$ masy ciała. Zbyt ciężkie tornistry, których obciążenia przekraczały $15 \%$ masy ciała, nosiło ponad połowę uczniów klas pierwszych i ponad $40 \%$ klas drugich.

Przeprowadzone badania wykazały, że największy średni ciężar plecaków występował u uczniów klas drugich. Analiza statystyczna wykazała występowanie istotnych statystycznie różnic $(p=0,005)$ między ciężarem tornistra klasy pierwszej a drugiej. Średni ciężar plecaka był istotnie statystycznie większy w klasie drugiej w porównaniu do klasy pierwszej. W klasie trzecie zaobserwowano nieznaczne obniżenie średniego ciężaru tornistra w porównaniu do klasy drugiej.

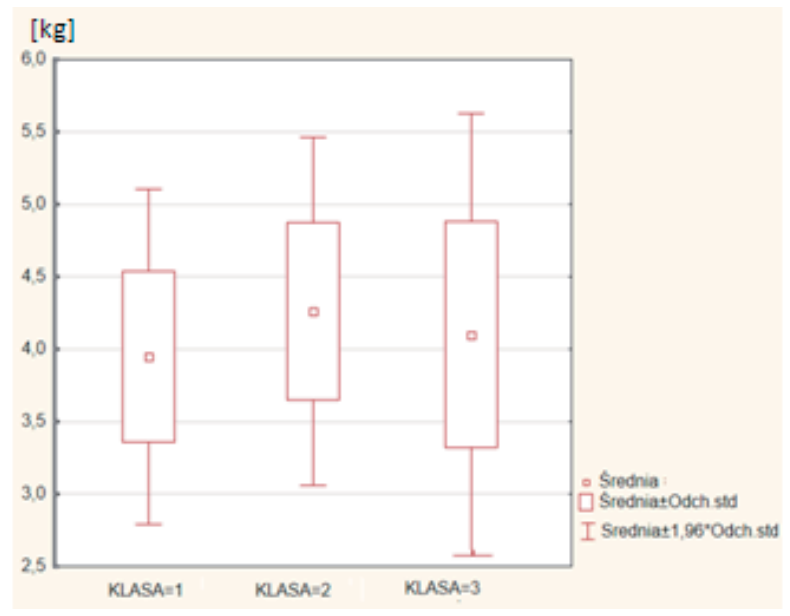

Rycina 4. Średni ciężar tornistrów [kg] w badanych klasach
Przeprowadzona analiza wyników wykazała, że mimo wzrostu średniej ciężaru plecaka wraz z wiekiem, procentowy ciężar tornistra w stosunku do masy ciała ulega zmniejszeniu. Dzieci uczące się w pierwszych dwóch klasach miały najcięższe tornistry w stosunku do swojej masy ciała, średni ciężar ich plecaków przekraczał 15\% masy ciała.

\section{Dyskusja}

Dzieci obciążane nadmiernym ciężarem tornistrów narażone są na przeciążenia narządu ruchu i coraz częściej uskarżają się na dolegliwości kręgosłupa. Obciążenia powyżej $15 \%$ masy ciała mają niekorzystny wpływ na postawę ciała, równowagę i chód dzieci, ponadto zaburzają pracę układu krążeniowo-oddechowego [5-9].

Z analizy badań własnych wynika, że zalecany przez Pracowników Państwowej Inspekcji Sanitarnej dla uczniów klas I-III ciężar tornistra (3 kg), występował u niespełna $7 \%$ badanych dzieci. Porównując ciężar tornistra do masy ciała, wykazano, że jedynie 11\% badanych miało plecaki ważące do $10 \%$ masy ciała. Ciężkie tornistry przekraczające $15 \%$ masy ciała najczęściej występowały u uczniów klas I (54\%) i drugich (42\%).

Również badania prowadzone w różnych rejonach Polski przez stacje sanitarno epidemiologiczne ukazują problem przeciążania dzieci nadmiernym ciężarem plecaka. Z przedstawionego raportu pracowników Państwowej Inspekcji Sanitarnej województwa warmińsko-mazurskiego w 2009 r. wynika, że spośród 1933 uczniów klas I i II obciążenia nie przekraczające $10 \%$ masy ciała stwierdzono u 37\% pierwszoklasistów i 38\% drugoklasistów, natomiast u 16\% badanych plecaki przekraczały dopuszczalne 15\% masy ciała. Zbyt ciężkie plecaki częściej stwierdzono u dziewczęta w porównaniu do chłopców [18].

Podobną tendencję również wykazano w badaniach własnych, w których zaobserwowano, że dziewczęta częściej niż chłopcy nosiły plecki, których ciężar przekraczał $15 \%$ masy ciała.

Badania oceniające ciężar tornistrów przeprowadzone wroku szkolnym 2013/2014 w województwie lubuskim na 4987 dzieciach klas I-III szkół podstawowych wykazały, że tornistry przekraczające $15 \%$ masy ciała występowały u 27\% uczniów klas pierwszych, 36\% klas drugich i 30\% klas trzecich [19].

Z badań przeprowadzonych przez opolski sanepid w 2014 r. na 3254 uczniach klas I-III wynika, że plecaki ważące 10\% masy ciała występowały u 30\% uczniów klas I i 39\% klas II i III. Zbyt ciężkie tornistry ważące powyżej $15 \%$ masy ciała występowały u 21\% pierwszoklasistów i $20 \%$ uczniów klas drugich i trzecich. Kontrolna ocena przeprowadzona w marcu 2015 r. na 1558 uczniów klas 
I-III wykazała nieznaczny wzrost grupy pierwszoklasistów (22\%) z tornistrami powyżej 15\% masy ciała [20].

Porównanie wyników badań własnych do wyników przeprowadzonych przez pracowników Państwowej Inspekcji Sanitarnej w województwie opolskim wskazuje na wzrastającą skalę problemu i powinno budzić niepokój o zdrowie dzieci.

Dzieci chodząc do szkoły każdego dnia muszą dźwigać na swoich plecach tornistry, które są wielokrotnie zakładane i ściągane z pleców, a także przenoszone często na znaczne odległości. Zazwyczaj podnoszenie i zakładanie plecaka wykonywane jest podświadomie i nawykowo w ten sam sposób. Powtarzane każdego dnia czynności z czasem mogą doprowadzić do jednostronnych przeciążeń mięśni i bólu pleców oraz niekorzystnie wpłynąć na kształtującą się postawę ciała. Zbyt ciężkie plecaki noszone na ramionach przez dłuższy czas mogą powodować mikrostrukturalne uszkodzenia tkanek miękkich oraz nerwów ramion i szyi [21, 22].

Badania prowadzone przez Walicką-Cupryśs i wsp. wykazały, że w przypadku zwiększenia ciężaru plecaka skróceniu ulega odcinek lordozy lędźwiowej i zmniejsza się pochylenie kości krzyżowej [24].

Nadmierne obciążenia mogą mieć negatywny wpływ na strukturę i funkcjonalność stóp szczególnie u dzieci z nadwagą i otyłością. Duże obciążenia powodują znaczny wzrost przeciążeń w przedniej części stóp. Autorzy sugerują, że wydłużony czas działania zbyt dużych obciążeń może zwiększać ryzyko wystąpienia bólu w stopie i być głównym czynnikiem inicjującym zmiany w budowie stóp i kręgosłupie [23]

W świetle powyższych badań, jak najszybciej powinny zostać podjęte odpowiednie kroki ustalające prawnie normy wagowe dla noszonych przez dzieci ciężarów. Brak tych norm powoduje, zrzucanie odpowiedzialności za przeciążanie dzieci zbędnym ładunkiem z nauczycieli na rodziców i odwrotnie. Ciągłe zmiany w Polskim systemie edukacji dodatkowo nie sprzyjają rozwiązaniu tego problemu, a wręcz wskazują na zwiększenie się skali występowania zbyt ciężkich plecaków.

Przeprowadzone badania wskazują, że dzieci nie mają wyrobionych nawyków systematycznej kontroli zawartości swoich plecaków: w domu nie rozpakowują swoich tornistrów, a jedynie dokładają dodatkowe książki. W tej kwestii, jak widać, również zawodzi opieka rodzicielka. Nasze spostrzeżenia potwierdzają również badania prowadzone przez Forjuoh [25], które wskazują, że rodzice częściej zwracają uwagę na zawartość szkolnych plecków swoich dzieci (2/3 badanych), natomiast tylko w sporadycznie (4\% badanych) kontrolują noszony przez dzieci ciężar.
Brak systematycznej kontroli zarówno ze strony rodziców, jaki i nauczycieli, słabaijak widać nieskuteczna edukacja uświadamiająca dzieci, w jaki sposób pakować plecaki i jakie książki w nich nosić, sprawia, że znaczna grupa dzieci dźwiga każdego dnia zbyt ciężkie tornistry.

\section{Wnioski}

Szkoła powinna być środowiskiem przyjaznym dla rozwoju i zdrowia dzieci, gdyż wywiera na nie bezpośredni wpływ. W szkole dzieci spędzają każdego dnia kilka godzin i również nie bez znaczenia dla ich rozwoju jest noszony przez nie tornister. Badania wykazały że znaczna grupa dzieci dźwiga na swoich placach zbyt duże ciężary. Nadmierne obciążenie tornistrem niewątpliwie ma negatywny wpływ na zdrowie dziecka, powodując zmiany w postawie ciała, które mogą inicjować dolegliwości bólowe i coraz częściej są przyczyną zwiększających się wad postawy. Zatem należałoby podjąć zintegrowane kroki mające za zadanie zminimalizowanie obciążeń kręgosłupa szkolnym plecakiem, tak by rosnące młode pokolenie w przyszłości było zdrowsze i wolne od bólu.

\section{Oświadczenia}

Oświadczenie dotyczące konfliktu interesów Autorzy deklarują brak konfliktu interesów.

\section{Źródła finansowania}

Autorzy deklarują brak źródeł finansowania.

Piśmiennictwo

1. Harreby M, Nygaard B, et al. Risk factors for low back pain in a cohort of 1389 Danish school children: an epidemiologic study. Eur Spine J. 1999; 8: 444-450.

2. Grajda A, Kułaga Z. Nadmierne obciążenie kręgosłupa uczniów tornistrami. Bezpieczeństwo Pracy. 2007; 9: 4-7.

3. De Paula AJF, Silva JCP, Silva JCRP. The influence of load imposed by the backpack school in children and teens in Brazil. Procedia Manufacturing. 2015; 3: 5350-5357.

4. Aprile I, Di Stasio E et al. The relationship between back pain and schoolbag use: A cross-sectional study of 5,318 Italian students. Spine Journal. 2016; 16 (6): 748-755.

5. Hong Y, LI JX, Wong AS, Robinson PD. Effects of load carriage on heart rate, blood pressure, and energy expenditure in chil dren. Ergonomics. 2000; 43: 717-727.

6. Negrini S, Carabalon R. Backpacks on! Schoolchildren's perceptionsof load, associations with back pain and factors determining the load. Spine 2002; 27: 187-95.

7. Hong $Y$, Cheung C. Gait and posture response to backpack load during level walking in children. Gait and Posture, 2003; 17: 28-33.

8. Reneman MF, Poels BJ, Geertzen JH, Dijkstra PU. Back pain and backpacks in children: biomedical or biopsychosocia model? Disabil Rehabil. 2006; 28, 20: 1293-1297.

9. Cotralorda J, Rahmani A, Diop M, Gautheron V, Ebermeyer $E$, Belli $A$. Influence of school bag carrying on gait kinetics. J Pediatr Orthop B. 2003; 12: 357-364

10. Chow DHK, Ou ZY, Wang XG, Lai A. Short-term effects of backpack load placement on spine deformation and repositioning er ror in schoolchildren. Ergonomics. 2010; 53(1): 56-64. 
11. Pau M, Leban B, Pau M. Alterations in the plantar pressure patterns of overweight and obese schoolchildren due to backpack carriage. J Am Podiatr Med. Assoc. 2013; 103(4): 306-323.

12. Janiszewska R, Tuzinek S, Nowak S i wsp. Nieprawidłowości postawy ciała u dzieci 6-12 letnich - uczniów szkół podstawowych z Radomia - badania pilotażowe. Probl Hig Epidemiol. 2009; 90(3): 342-346.

13. Maciałczyk-Paprocka K. Epidemiologia wad postawy ciała. Praca doktorska. Poznań 2013 http://www.wbc.poznan.pl/ Content/289363/index.pdf (data dostępu10.06.2018).

14. Mikołajczyk E, Jankowicz-Szymańska A, Wojtanowski W, Janusz M. Postawa ciała w płaszczyźnie strzałkowej dzieci w wieku przedszkolnym Hygeia Public Health. 2015; 50(1): 26-30.

15. Hagner W, Bąk D, Hagner-Derengowska M. Zmiany w postawie ciała u dzieci w pierwszych trzech latach nauki szkolnej. Forum Medycyny Rodzinnej. 2010; tom 4, nr 4, 287-290

16. Rosa K, Muszkieta R, Zukow W, Napierała M, Cieślicka M. Częstość występowania wad postawy u dzieci z klas I-III Szkoły Podstawowej. Journal of Health Sciences. 2013; 3(12): 107-136.

17. Mastalerz-Migas A, Krupa T, Muszyńska A. i wsp. Epidemiologia wad postawy u dzieci i młodzieży na terenie województwa opolskiego. Family Medicine \& Primary Care Review. 2006; 8, 3: 692-694.

18. Raport państwowej inspekcji sanitarnej województwa warmińsko-mazurskiego z akcji ważenia plecaków. 2009. http:// oswiata.sanepid.olsztyn.pl/wp-content/uploads/2010/08/ Akcja-wa\%C5\%BCenia-plecak\%C3\%B3w-raport.pdf (data dostępu 15.05.2018).

19. Rydzaj I, Woźniczka A. Obciążenie uczniów szkół podstawowych województwa lubuskiego tornistrami/plecakami - wyniki badań za rok szkolny 2013/2014. http://wsse.gorzow. pl/o-nas/aktualnosci/456-za-ciezkie-tornistry (data dostępu 15.07.2018).
20. Gudełajtis M. Ciężkitornister czyj problem? Materiały z konferencji „Edukacja dla zdrowia” Opole 2018 http://www.kuratorium opole.pl/wp-content/uploads/2018/04/m.-gudelajtis-wsseopole-konferencja-05.04.2018-r..pdf (data dostępu 15.07.2018).

21. Nylund T, Mattila VM. Salmi T. et al. Recovery of brachial plexus lesions resulting from heavy backpack use: a follow-up case series. BMC Musculoskelet Disord. 2011; 12: 62.

22. Avantika R, Shalini A. Back problems due to heavy backpacks in school children," IOSR Journal of Humanities and Social Science. 2013; 10, 6: 22-26.

23. Pau M, Leban B, Corona F, Gioi S, Nussbaum MA. Schoolbased screening of plantar pressures during level walking with a backpack among overweight and obese schoolchildren. Ergonomics. 2016; 59(5): 697-703.

24. Walicka Cupryś K, Skalska-Izdebska R, Rachwał $M$, Truszczyńska A. Influence of the Weight of a School Backpack on Spinal Curvature in the Sagittal Plane of Seven-YearOld Children; BioMed Research International Volume. 2015 Article ID 817913, 6 pages.

25. Forjuoh SN, Little D, Schuchmann JA, Lanea BL Parental knowledge of school backpack weight and contents. Arch Dis Child. 2003; 88: 18-9.

Zaakceptowano do edycji: 15.12.2019

Zaakceptowano do publikacji: 15.02.2020

\section{Adres do korespondencji:}

Karina Stonka

Instytut Fizjoterapii, Katedra Podstaw Fizjoterapii

ul. Prószkowska 76

45-758 Opole

tel. 609405781

e-mail: k.slonka@po.opole.pl 